\title{
Wastewater treatment systems selection inside watersheds by using multiobjective analysis
}

\author{
Seleção de sistemas de tratamento de esgotos no âmbito de bacias hidrográficas a partir do \\ emprego da análise multiobjectivo
}

\author{
Luiza Mayer Bringer ${ }^{1}$, José Antonio Tosta dos Reis $^{1}$ and Antonio Sérgio Ferreira Mendonça ${ }^{1}$ \\ ${ }^{1}$ Universidade Federal do Espirito Santo, Vitória, ES, Brasil \\ E-mails: luizambringer@gmail.com (LMB), jatreis@gmail.com (JATR), ansermf@terra.com.br (ASFM)
}

Received: August 27, 2017 - Revised: January 26, 2018 - Accepted: January 29, 2018

\begin{abstract}
In order to determine required wastewater treatment plants (WWTP's) efficiencies, several methodologies have been proposed to assist the sewage treatment systems process selection, usually aiming to achieve economic objectives. However, in water resources problems solving, search involves multiple and conflicting objectives. This work used, for Pardo's river basin (Espírito Santo State, Brazil), water quality simulation model, optimization technique and multiobjective analysis for selecting sewage treatment systems, taking into account Brazilian environmental effluents Biochemical Oxygen Demand standards, imposed by CONAMA Resolution 430/2011. After proposing an optimization model that allowed the estimation of minimum organic matter removal efficiencies, a multiobjective analysis was applied by using the ELECTRE III method, which selected sewage treatment systems for localities responsible for domestic wastewater disposal in Pardo's river basin. The results indicated that keeping the effluents standards can produce treatment plants overestimation and inadequate allocated financial resources distribution for sewage treatment plants implementation. Treatment systems such as Submerged Aerated Biofilters (with Nitrification), Wetlands and Facultative Ponds were the most selected, considering different contexts appreciated in this work.
\end{abstract}

Keywords: Water quality model; Genetic algorithm; Multiobjective analysis; ELECTRE; Sewage treatment.

\section{RESUMO}

Buscando-se determinar níveis de remoção requeridos para estações de tratamento de esgotos (ETEs), diversas metodologias têm sido propostas para auxílio aos processos de seleção de sistemas de tratamento de esgotos, visando, usualmente, atingir objetivos de natureza econômica. No entanto, em sistemas de recursos hídricos, a busca pela solução de problemas envolve objetivos múltiplos e conflitantes. O presente trabalho empregou, para a bacia hidrográfica do rio Pardo (Espírito Santo, Brasil), modelo de simulação da qualidade da água, técnica de otimização e análise multiobjetivo para selecionar sistemas de tratamento de esgotos, considerando-se os padrões para a demanda bioquímica de oxigênio em efluentes, impostos pela Resolução CONAMA n 430/2011. Após a proposição de um modelo de otimização, que levou à indicação de eficiências mínimas de tratamento necessárias, foi aplicado o método ELECTRE III, que indicou sistemas de tratamento de esgotos para as localidades responsáveis pela disposição de esgotos brutos na bacia hidrográfica do rio Pardo. Os resultados indicaram que a conservação dos padrões estabelecidos para os efluentes pode levar à superestimativa de plantas de tratamento e distribuição inadequada dos recursos financeiros destinados à implantação de ETEs. Sistemas como Biofiltro Aerado Submersos (com Nitrificação), Wetlands e Lagoas Facultativas foram os mais selecionados, considerando os contextos avaliados neste trabalho.

Palavras-chave: Modelo de qualidade de água; Algoritmo genético; Análise multiobjetivo; ELECTRE; Tratamento de esgotos. 


\section{INTRODUCTION}

In the accelerated urban development context in various parts of the world, wastewater treatment plants (WWTP) are key technologies for meeting restrictive environmental and public health standards. Required WWTP's treatment levels depend on receiving bodies self-purification capacities, water uses downstream discharges points and discharges characteristics and conditions (JORDÃO; PESSOA, 2014). However, scarcity of water, increasing number of alternatives available for effluents treatment and growing pressure related with projects technical, environmental, economic and social balances are aspects that turn difficult WWTPs installing process decisions (CASTILLO et al., 2017), especially if analyzed within a watershed where different water bodies potential polluters are involved.

In Brazil, beyond National Water Resources Policy (BRASIL, 1997) watersheds water resources management implementation, the Basic Sanitation Law (BRASIL, 2007) adopted watersheds as reference units for actions planning. However, multiple combination of factors, related with each geographic space, involving physiographic, institutional, socio-cultural and economic aspects, requires important analytical and methodological efforts to address the sanitation issue with focus on water resources protection (ANA, 2017).

In general, several methodologies have been developed for producing tools to assist sewage treatment systems selection processes (SOUZA; FORSTER, 1996; SOUZA; CORDEIRO; SILVA, 2009), differentiating themselves, as Hamouda, Anderson and Huck (2009) suggest, in three different approaches: (1) technical design, which considers information on treatment alternatives efficiency and effectiveness; (2) technical and economic analysis, which usually uses cost as a decision variable; and (3) system analysis, or "appropriate technology analysis", through which technological choice represents different technical, economic, social, environmental and cultural criteria point of convergence and harmonization.

Associated with the technical and economic approach, Burn and Yulianti (2001), Cho, Seok Sung and Ryong Ha (2004), Aras, Togan and Berkun (2007) and Han et al. (2012) works considered watercourses self-purification capacities in effluent allocation problems, using water quality simulation models and optimization techniques. In this type of problem, objective functions usually consist of minimizing costs and water quality degradation, in order to determine the removal level required for each effluent source to maintain or reach satisfactory water quality, in economically feasible and efficient conditions.

On the other hand, Nikoo, Kerachian and Niksokhan (2012), Mahjouri and Bizhani-Manzar (2013), Cho and Lee (2014), Lei et al. (2015), Ashtiani, Niksokhan and Jamshidi (2015), Nikoo, Beiglou and Mahjouri (2016), Valory, Reis and Mendonça (2016) and Fantin, Reis and Mendonça (2017) works, in addition to minimizing treatment costs, incorporated into the wastewater management problem the "Polluter Pays Principle", which, in turn, expresses the notion that as greater the responsibility for pollution, greater should be the amount paid by the polluter. Thus, these studies considered costs distribution fairness principles, either in the search for water courses self-purification capacities adequate apportionment, or in the search for adequate costs distribution, also through water quality modeling and optimization techniques. Among the different techniques used to solve optimization problems, the water resources planning and management area has seen considerable increase in the development and application of several types of evolutionary algorithms, given their potential for solving nonlinear, non-convex, multimodal and discrete problems. Among the evolutionary algorithms, Genetic Algorithms (GA) have been frequently used (NICKLOW et al., 2010; GARCIA, 2011).

Although costs are relevant in the water resources decisionmaking process, the search for problem solving involves multiple and conflicting objectives. Thus, under the appropriate technologies approach, multiobjective analysis is often used to assist the sewage treatment systems choice process, given the wide variety of technologies available and the various factors involved in the decision- making process (MOLINOS-SENANTE et al., 2015). The multiobjective analysis constitutes a set of techniques that aid the decision-making process, taking into account the influential factors complexity and society interests (SOUZA; CORDEIRO; SILVA, 2009). The different perspectives, values and preferences of those responsible and impacted by the decisions are important factors that add complexity to the decision-making process (MARTTUNEN; LIENERT; BELTON, 2017).

Based on different principles and applying different procedures for punctuation, weighting and aggregation, many multiobjective analysis methods were developed (MARTTUNEN; LIENERT; BELTON, 2017). In general, in environmental problems, Analytic Hierarchy Process (AHP), Analytic Network Process (ANP), Elimination Et Choix Traduisant la Realité, (ELECTRE), Multi-Attribute Value Theory / Analysis (MAVT), Multi -Attribute Utility Theory / Analysis (MAUT), Preference Ranking Organization Method for Enrichment Evaluation (PROMETHEE), and Technique for Order Preference by Similarity to Ideal Solution (TOPSIS) (HUANG; KEISLER; LINKOV, 2011) are the most used methods. Zeng et al. (2007), Bottero, Comino and Riggio (2011), Kalbar, Karmakar and Asolekar (2012), Hunt (2013), Cornelli (2014), Molinos-Senante et al. (2015), Ouyang et al. (2015), Castillo et al. (2017) and Golfi (2017), are works examples that, through multiobjective analysis, sought the selection of sewage treatment systems for given localities. However, in sanitation management context with focus on water resources protection, it is necessary to adopt a methodology based on watershed territorial cut.

Technology selection for a given location alone is a highly complex problem. Different areas appropriate technologies choice (analyzed together in a multi-layer basin with different water bodies presenting different assimilation capacities) further elevates the difficulty level. Since downstream watercourse quality is affected by upstream conditions, wastewater treatment facilities cannot be considered isolated from each other (RAHM et al., 2013).

In this perspective, the present work has studied water quality simulation model, optimization technique and multiobjective analysis use to conform sewage treatment systems selection process, within watersheds. It should be noted that, among the methodologies that have been developed to assist the decision-making process regarding wastewater planning and management it is not observed the use of water quality modeling and optimization techniques together with the multiobjective analysis methods, given that, while the former two are usually associated with the technical 
and economic approach, the latter is related to the appropriate technology analysis approach.

The selection process addressed in this study considered Biochemical Oxygen Demand conditions established for effluents release through CONAMA Resolution 430/2011 (BRASIL, 2011), aiming to evaluate these restrictions imposition consequences in the context of the search for adequate water bodies self-purification capacities distribution among polluters. Although the methods adopted here are intended to be generic and applicable to any watershed, in this study there were employed in the Pardo watershed, watercourse located in Espírito Santo State, Brazil.

\section{STUDY AREA}

The proposed methodology was applied to the Pardo river watershed (Figure 1). Pardo is a Braço Norte Esquerdo river affluent and this is an Itapemirim river tributary. Itapemirim is the most important watercourse in the Espírito Santo State southern portion. Pardo River main spring located in Ibatiba municipality (ES), at an altitude of approximately 1,244 meters, and its mouth is localized at an about 400 meters altitude. In its watershed are located parts of Ibatiba, Irupi, Iúna, Muniz Freire and Lajinha municipalities - the latter located in Minas Gerais State. Pardo river watershed comprises about 611 square kilometers drainage area. Pardo river length corresponds to approximately 57.9 kilometer. Pardo watershed water system is composed by Pardo river and three tributaries of greater relevance (São José river, Pardinho river and Ribeirão Perdição creek). As may be observed in Figure 2, the Pardo River receives domestic sewage from Ibatiba and Iuna municipalities. The Pardinho river, in turn, has its quality altered by Irupi municipality sanitary sewage. Santíssima Trindade and Nossa Senhora das Graças villages discharge wastewater in the Ribeirão Perdição creek. In none of the effluent disposal points there exists Sewage Treatment Plants (SWT).
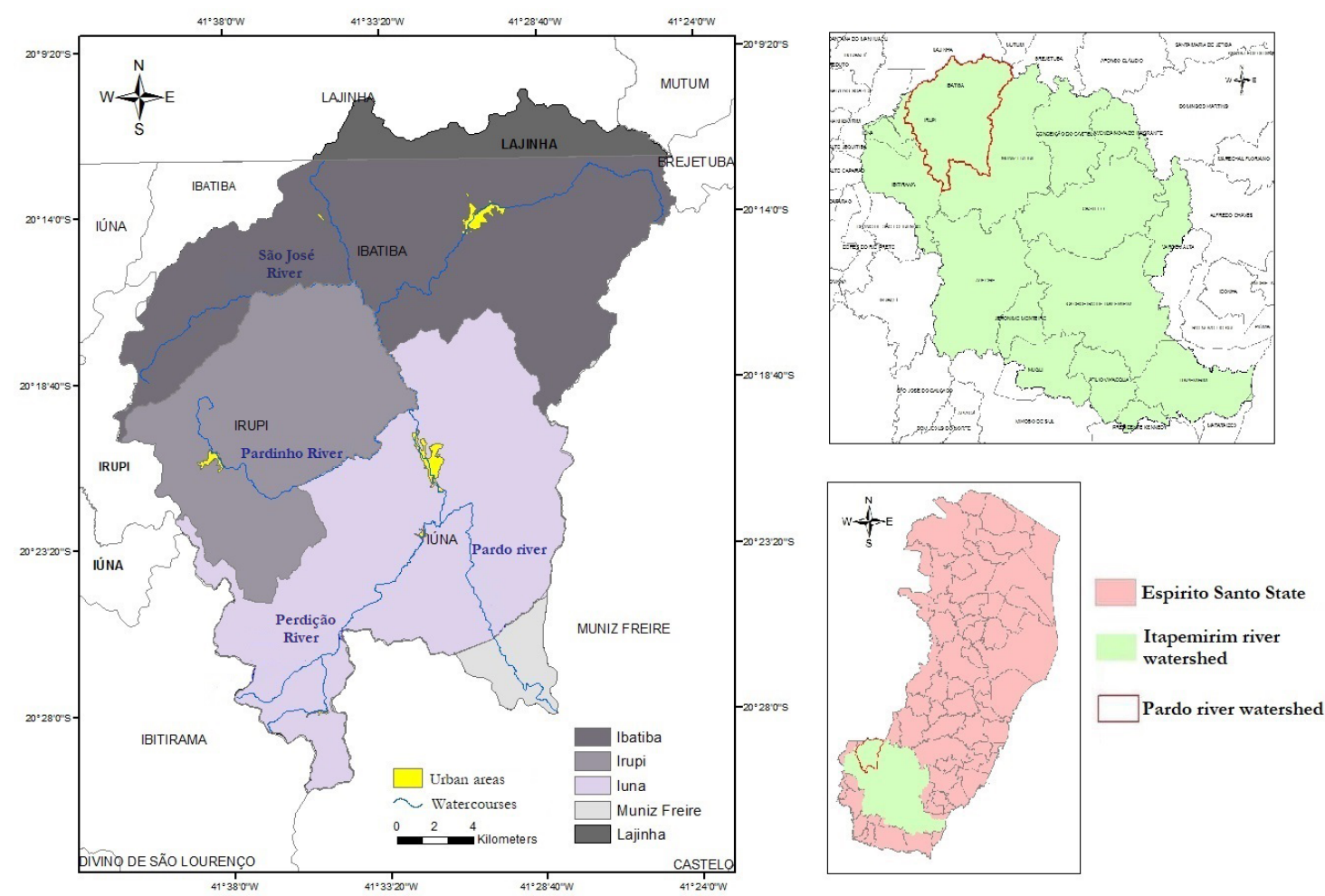

Figure 1. Pardo River watershed location.

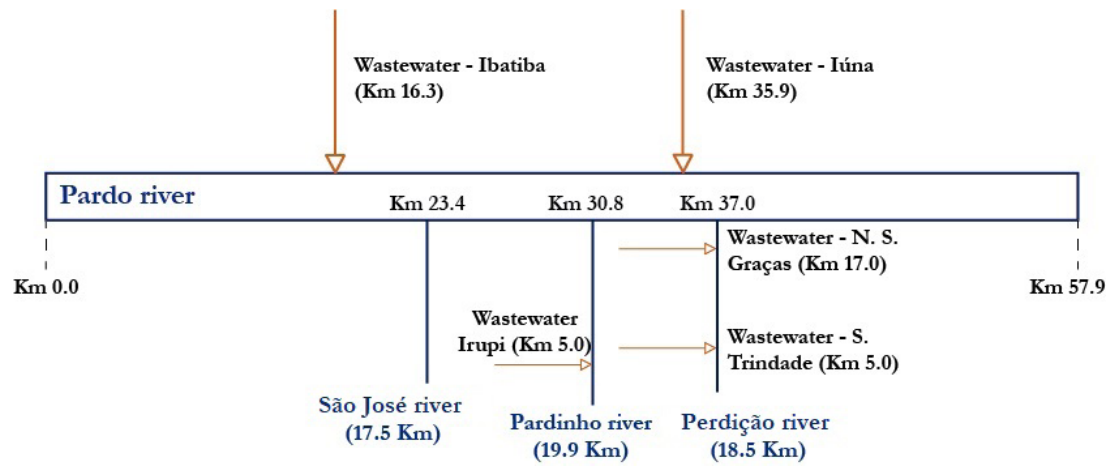

Figure 2. Pardo river watershed single-line diagram. 


\section{MATERIAL AND METHODS}

The methodology used in this study presents as main objective to subsidize the decision-making process associated to domestic sewage treatment systems selection, in the context of watersheds. In order to do so, it involves (1) minimum sewage treatment efficiencies required for each effluent disposal point determination stage; and (2) possible treatment technologies, from a preference structure, hierarchical stage.

\section{Minimum sewage treatment efficiency determination}

Aiming at reducing wastewater treatment costs, the self-purification concept was incorporated into the wastewater treatment systems choice process. Thus, a water quality model and an optimization technique were applied in order to determine the minimum sewage treatment efficiencies that, within the watershed, would allow respect to the established water receiving bodies environmental standards.

\section{Water quality simulation model}

The water quality simulation was performed by the computational model developed by Valory, Reis and Mendonça (2016), in the MATLAB software environment, adapted to the Pardo river watershed. This model encompasses the physical mixing interactions and biological reactions that characterize water body natural self-purification process, reproducing QUAL-UFMG model, originally presented and discussed by Von Sperling (2007), mathematical formulations and conceptual and computational structures,

The raw effluents kinetic constants, hydrodynamic information and organic loads considered in the study (Table 1) were obtained from Calmon et al. (2016), who proposed a methodology to support surface watercourses water intended uses classification processes,

Table 1. Pardo river watershed raw effluents kinetic constants, hydrodynamic variables and organic loads.

\begin{tabular}{lc}
\hline \multicolumn{1}{c}{ Parameter } & Value \\
\hline Average altitude & $846.36 \mathrm{~meters}$ \\
Average temperature & $20.6^{\circ} \mathrm{C}$ \\
Oxygen saturation concentration & $8.11 \mathrm{mg} / \mathrm{L}$ \\
Watercourses incremental flow & $3.53 \mathrm{~L} / \mathrm{s}$ \\
Watercourses DO & $7.5 \mathrm{mg} / \mathrm{L}$ \\
Watercourses BOD & $2 \mathrm{mg} / \mathrm{L}$ \\
Sewage DO & $0 \mathrm{mg} / \mathrm{L}$ \\
Sewage BOD & $400 \mathrm{mg} / \mathrm{L}$ \\
Ibatiba sewage discharge & $24.3 \mathrm{~L} / \mathrm{s}$ \\
Irupi sewage discharge & $5.20 \mathrm{~L} / \mathrm{s}$ \\
Iúna sewage discharge & $19.90 \mathrm{~L} / \mathrm{s}$ \\
Santíssima Trindade sewage discharge & $0.30 \mathrm{~L} / \mathrm{s}$ \\
Nossa Senhora das Graças sewage discharge & $0.60 \mathrm{~L} / \mathrm{s}$ \\
Direct incremental BOD load & $9.35 \mathrm{~g} / \mathrm{day} \cdot \mathrm{meter}$ \\
\hline Source: Calmon et al. (2016)
\end{tabular}

Source: Calmon et al. (2016). with application in the same watershed considered in this work. Calmon et al. (2016) also established flow velocity and depth adjustment equations, based on Thomann and Mueller (1987). The $K_{D}$ coefficient was evaluated by the authors according to the water body hydraulic characteristics (depth and flow), considering the formulation proposed by EPA (1985) and Thomann and Mueller (1987). The kinetic atmospheric reaeration constant (K2) was estimated from the original expression defined by O'Connor and Dobbins in 1958, considering the relations between flow and velocity and between flow and depth.

For BOD concentrations simulation, only the deoxygenation phenomena associated with organic matter oxidation and the external fuzzy loads contributions were considered. For DO concentrations simulation, atmospheric reaeration and deoxygenation produced by organic matter oxidation were considered.

According to Von Sperling (2014a), the organic matter sedimentation disregard is in favor of results safety, since the BOD model does not consider the BOD decrease coming from it. In addition, photosynthesis and respiration processes present approximately equal rates, and can be equivalent for water quality simulations that assume permanent flow. The author also indicates that, with respect to the lack of consideration associated with benthic demand, the studies for quantification of the benthic demand coefficient are laborious and expensive, demanding large quantity of field surveys and laboratory analyzes. The use of average data from the literature is difficult to generalize, due to the complexity of all factors interaction that may influence benthic demand (sludge composition and texture, organic matter percentage, age, depth, temperature, DO, among others).

\section{Optimization model}

Aiming to estimate the minimum sewage treatment efficiencies and in the search for an adequate apportionment of water bodies autodepuration capacity among polluters, an optimization model that imposes the minimization of an inequality measure between treatments was proposed. This model is based on Santoro, Reis and Mendonça (2016) work conclusions. The authors evaluated different optimization models applied to the determination of sewage treatment efficiencies in the Pardo river watershed. Some of the models tested by these authors did not present adequate performances, due to the existence of multiple sewage discharges presenting very different raw sewage loads and water bodies presenting different assimilation capacities. Thus, it was opted for an optimization model proposition that would include the different environmental conditions existing in a watershed (Equation 1).

$$
\operatorname{Min}[f(E)]=\sum_{i=1}^{n} \sum_{j=i+l}^{n}\left|\frac{C O e_{(i)} \cdot B O D r_{(i)}}{E_{(I)} \cdot Q r_{(I)}}-\frac{C O e_{(j)} \cdot B O D r_{(j)}}{E_{(I)} \cdot Q r_{(I)}}\right|
$$

in the Equation 1: COe(i): i-th effluent disposal point considered in the watershed raw organic load, in $\mathrm{mg} / \mathrm{s}$; BODr(i): BOD concentration in the water stream immediately before the $\mathrm{i}$-th effluent disposal point, in $\mathrm{mg} / \mathrm{L}$; E(i): i-th effluent treatment system 
BOD removal efficiency; Qr(i): watercourse flow immediately before the i-th effluent disposal point, in $\mathrm{L} / \mathrm{s}$.

The proposed model presents as main purpose to consider the recipient water bodies condition immediately upstream the raw domestic sewage discharges. Thus, the $\frac{C O e_{(i)} \cdot B O D r_{(i)}}{E_{(i)} \cdot Q r_{(i)}}$ relationships indicate that streams with higher flow rates present greater sewage assimilation capacity, while water courses presenting higher BOD concentrations have lower assimilation capacity, given their lower quality conditions upstream the releases. Based on these considerations, the lower the watercourse assimilation capacity and the greater the organic load discharged, the greater the required sewage treatment efficiency for that wastewater discharge point. The model purpose is to minimize the sum of said relationships differences between effluent disposal points, which, therefore, establishes an inequality measure between final disposal points.

The objective function was subjected to constraint inequalities (inequalities from 2 to 13) based on both sewage treatment efficiency limits and quality standards established by Brazilian CONAMA Resolution 357/2005 (BRASIL, 2005) for Class II watercourses and on sewage discharge conditions with respect to BOD (CONAMA Resolution 430/2011). Thus, the constraints that conformed the optimization models established three different final effluents disposal analysis conditions:

\section{Effluent Discharge Condition 1:}

$E_{(i)} \leq 90 \%$

$D O_{\text {Watercourse }} \geq 5$

$B O D_{\text {Watercourse }} \leq 5$

$E_{(i)} \geq 60 \%$

\section{- Effluent Discharge Condition 2:}

$E_{(i)} \leq 90 \%$

DO $O_{\text {Watercourse }} \geq 5$

$B O D_{\text {Watercourse }} \leq 5$

$B O D_{\text {Treated Effluent }} \leq 120 \mathrm{mg} / \mathrm{L}$

\section{- Effluent Discharge Condition 3:}

$E_{(i)} \leq 90 \%$

DO $O_{\text {Watercourse }} \geq 5$

$B O D_{\text {Watercourse }} \leq 5$

$E_{(i)} \geq 1 \%$
It is important to highlight that Inequality 13, besides allowing watercourse self-purification capacity exploration, aims to guarantee non-negative estimated sewage treatment efficiencies values.

\section{Optimization tecnique}

For the proposed optimization model application it was utilized the Genetic Algorithm (GA) technique. Originally established by John Holland, in 1975, at the University of Michigan, and popularized by one of his students, David Goldberg, the GAs belong to the class of probabilistic search and optimization methods that attempt to direct the search to space regions where it is likely that solutions are (TANOMARU, 1995). They were inspired by the species evolution mechanisms, including population genetics processes, survival and individuals adaptation.

Lacerda and Carvalho (1999) point out that the first step of GA is the generation of an "initial chromosomes population", which is formed by a random set of chromosomes that represents problem possible solutions. During the "evolutionary process", this population is evaluated and each chromosome receives a note, called "aptitude", which reflects the quality of the solution it represents. In general, the fittest chromosomes are selected and the least discarded (Darwinism). The selected "individuals" can undergo changes in their fundamental characteristics through "crossover" and "mutation" operators, generating offspring for the next generation. This process is repeated until a satisfactory solution is found.

Thus, the basic idea of GAs is to treat possible solutions to the problem as "individuals" of a "population", which will "evolve" at each iteration or "generation" (POZO, 2005), been strongly dependent on the genetic operators performance (GREFENSTETTE, 1986; GEN; CHENG, 1996 apud LEIRAS, 2010).

The AG parameters operators and values used in this work (Table 2) reproduced those used by Valory, Reis and Mendonça (2016). When estimating sewage treatment efficiencies for hypothetical effluent releases in the upper portion of the Santa Maria da Vitória river watershed (Espírito Santo, Brazil), these authors performed tests with the main GA parameters and their respective more commonly used values in water quality management problems. In this work stage the functions available in the Toolbox "Optimization" of MATLAB software were used.

Table 2. Operators and parameters used in GA application.

\begin{tabular}{cc}
\hline $\begin{array}{c}\text { Operator/ } \\
\text { parameter }\end{array}$ & Value/Type \\
\hline Codification & Real \\
Population size & 300 individuals \\
Selection type & Tournament (10 individuals group) \\
Crossover type & Arithmetic \\
Crossover rate & $50 \%$ \\
Mutation type & Adaptive feasible \\
Stopping criteria & 100 gerations or results convergence \\
Elitism & 3 individuals \\
\hline
\end{tabular}

Source: Valory, Reis and Mendonça (2016). 


\section{Wastewater treatment systems for Pardo river watershed selection}

Considering the necessary effluent disposal sources treatment efficiencies in the watershed and aiming to incorporate into the sewage treatment systems selection process the Appropriate Technology corollaries, the final indication of the sewage treatment systems came from ELECTRE III - (ACHILLAS et al., 2013) application - using the "ELECTRE III-IV" software developed by the University of Paris - Dauphine Laboratory of Analysis and Modeling of Decision Support Systems (LAMSADE). ELECTRE is one of the European decision analysis school main and most used methods families (SOUZA; CORDEIRO; SILVA, 2009). Achillas et al. (2013) indicate that, in addition to being widely used in the field of waste management in general, ELECTRE III has been pointed out as one of the most appropriate methodologies for sewage treatment systems selection. It presents the advantage of being able to incorporate into the decision-making process a large number of quantitative and qualitative evaluation criteria (ACHILLAs et al., 2013), being therefore suitable for sewage treatment systems selection processes.

ELECTRE III makes peer-to-peer alternatives comparisons in order to accept, reject or, more often, evaluate the credibility of the statement "alternative ' $a$ ' is at least as good as alternative ' $b$ ", taking into account the indifference and preference thresholds defined for each criterion, the degree or importance coefficients (weights) assigned to each criterion and the possible relative comparability difficulties of two alternatives when the ' $a$ ' alternative is significantly better than the ' $b$ ' alternative in certain criteria, but much worse than the ' $b$ ' alternative in at least one of the criteria.

Thus, for each criterion, two indices are calculated. One expresses the extent to which the alternatives performances ' $a$ ' and ' $b$ ' are in agreement with the statement ' $a$ ' is higher than ' $b$ ' (concordance index), while the other expresses exactly the opposite - to what extent the performances of the alternatives oppose this statement (discordance index). The concordance indices associated with the criteria analysis weights give rise to a global concordance matrix, which expresses the extent to which all criteria performances are in agreement with the statement " " $a$ ' is greater than ' $b$ "'. Subsequently, a credibility matrix is established, which consists of the global concordance index weakened by the discordance indices, comprehensively expressing to what extent " " $a$ ' is greater than ' $b$ ". A classification algorithm is then used to obtain the final alternatives ordering.

Subsequent topics detail the steps in the method execution, considering the sewage treatment system selection applied to the Pardo river watershed problem.

\section{Alternatives and analysis criteria finite set definition}

Due to the lack of identification of local aspects that might prevent the adoption of certain treatment systems for the proposed methodology application, it was considered an initial set of 30 (thirty) sewage treatment alternatives presented by Von Sperling (2014b): conventional primary treatment (A01); advanced primary treatment (A02); facultative lagoon (A03); anaerobic lagoon + facultative lagoon (A04); optional aerated lagoon (A05); mixed aerated lagoon + sedimentation pond (A06); anaerobic lagoon + facultative lagoon + maturation lagoon (A07); anaerobic lagoon + facultative lagoon + high rate lagoon (A08); anaerobic lagoon + facultative lagoon + algae removal (A09); slow infiltration (10); rapid infiltration (A11); surface runoff (A12); wetlands (A13); septic tank + anaerobic filter (A14) + UASB reactor (A15); $\mathrm{UASB}+$ activated sludge (A16); UASB + submerged aerated biofilter (A17); UASB + anaerobic filter (A18); UASB + high load biological filter (A19); UASB + polishing ponds (A20); UASB + facultative aerated lagoon (A21); UASB + fully mixed aerated lagoon + decantation pond (A22); UASB + surface runoff (A23); activated sludge (A24); activated sludge prolonged aeration (A25); sludge activated sludge (A26); low load percolator biological filter (A27); biological filter high percolator (A28); submerged aerated biofilter with nitrification (A29) and; septic tank + biodisco (A30). However, only sewage treatment systems that do not involve effluent soil disposal (a function of these systems limitation to specific soils in which effluents would be released characteristics, particularly when disposing large sewage volumes) and that meet the minimum BOD removal efficiency obtained through water quality modeling and optimization technique.

In addition, in the decision-making process, seventeen criteria were considered, based on the quantitative and qualitative comparisons between the sewage treatment systems established by Von Sperling (2014b): nitrogen removal efficiency (Cr01); phosphorus removal efficiency (Cr02); coliforms removal efficiency (Cr03); demand by implantation area (Cr04); energy requirements (Cr05); implementation costs (Cr06); operating costs (Cr07); quantity of sludge to be treated (Cr08); quantity of sludge to be disposed (Cr09); resistance capacity to flow variations (Cr10); ability to withstand variations in tributary characteristics (Cr11); resistance capacity to toxic constituents ( $\mathrm{Cr} 12)$; operational simplicity (Cr13); odor generation ( $\mathrm{Cr} 14)$; noise generation $(\mathrm{Cr} 15)$; aerosols generation (Cr16) and insect attraction (Cr17).

\section{Alternatives performances}

Considering that ELECTRE III makes peer-to-peer sewage treatment alternatives comparisons by means of systems performances analysis in relation to each criterion, quantitative and qualitative comparisons between the sewage treatment systems data provided by Von Sperling (2014b) were made.

The ( $g(a))$ alternatives performance quantitatively compared by the aforementioned author were determined by using the linear values normalization technique, as performed by Hunt (2013) when establishing a multicriteria decision support model applied to small municipalities wastewater treatment systems selection. For Cr01 to $\mathrm{Cr} 03$ criteria the normalization equation took Equation 14 form. For $\mathrm{Cr} 04$ to $\mathrm{Cr} 09$ criteria values normalization was performed according to Equation 15.

$$
\begin{aligned}
& g(a)=\left(z_{i}^{k}\right)_{N}=10 \cdot \frac{z_{i}^{k}-z_{\text {min }}^{k}}{z_{\text {máx }}^{k}-z_{\text {min }}^{k}} \\
& g(a)=\left(z_{i}^{k}\right)_{N}=10 \cdot \frac{z_{\text {máx }}^{k}-z_{i}^{k}}{z_{\text {máx }}^{k}-z_{\text {min }}^{k}}
\end{aligned}
$$


in Equations 14 and 15: $z_{i}^{k}$ : alternative i value for criterion $\mathrm{k}$ (the considered values represent averages of the ranges indicated by Von Sperling (2014b)); $z_{\text {min }}^{k}$ : set of alternatives lowest value for criterion $\mathrm{k} ; z_{\text {máx }}^{k}$ : set of alternatives greatest value for criterion $\mathrm{k}$.

For $\mathrm{Cr} 10$ to $\mathrm{Cr} 17$ criteria, values normalization was not necessary because they were obtained from qualitative comparison made by Von Sperling (2014b).

\section{Weights, preference, indifference and veto thresholds definition}

ELECTRE III is a technique that uses anticipated preferences articulation. Hence, its application depends on the definition by the decision maker (s) of the degrees or importance coefficients attributed to the different criteria (weights) and $\alpha$ and $\beta$ coefficients values, necessary for the preference, indifference and veto thresholds calculation. The three thresholds can be defined and calculated, as following:

- The indifference threshold $\left(q=\alpha_{q} \cdot g(a)+\beta_{q}\right)$ corresponds to the greatest difference between the performances of two alternatives compatible with a situation of indifference;

- The preference threshold $\left(p=\alpha_{p} . g(a)+\beta_{p}\right)$ corresponds to the smallest performance difference of two alternatives from which the best performing alternative is strictly preferred;

- The veto threshold $\left(v=\alpha_{v} \cdot g(a)+\beta_{v}\right)$ is the smallest performance difference of two alternatives from which it cannot be accepted that the worst of the two alternatives (with respect to a given criterion) can be considered as good as the best alternative, even if its performance in all other criteria are better.

As it was not possible local preference structures identification (fundamental to the decision-making process), the values attributed by Cordeiro Netto, Souza and Lopes Júnior (2001) were adapted when analyzing alternatives for anaerobic reactors effluents post-treatment by using ELECTRE III as multiobjective analysis technique. It should be noted that many of the criteria adopted by them were more recently used in sewage treatment systems selection processes employing multiobjective analysis techniques (KARIMI et al., 2011; KALBAR et al., 2012; HUNT, 2013; CORNELLI (2014); MOLINOS-SENANTE et al., 2015). Thus, for Cr01 to Cr09 criteria, the alpha and beta values required to calculate the indifference and preference thresholds were, respectively, 0.05 and 0.00; and 0.15 and 0.00. For Cr10 to Cr17 criteria, the referred values were, respectively, 0.00 and 1.00; and 0.00 and 3.00. Considering that in developing countries costs are important aspects in sewage treatment systems selection processes, the veto threshold was considered only for criteria Cr05 and Cr06, so that, in a pairwise alternatives comparison, an expensive implantation and operation treatment system could not be considered as good as a much more economical. In this case, alpha and beta assumed values, respectively, 0.99 and 0.00 .
Table 3 summarizes the weights assigned to each criterion considered in this work.

\section{Concordance and discordance indices calculation}

Thresholds determination makes it possible to calculate concordance and discordance indices. Let $(a, b)$ be a pair of alternative sewage treatment systems. The concordance index $C_{j}(a, b)$, which aims to measure whether "alternative ' $a$ ' is at least as good as the alternative ' $b$ ' " in criterion $g_{j}$, is calculated by Equation 16.

$C_{j}(a, b)=\left\{\begin{array}{lr}\frac{P_{j}\left(g_{j}(a)\right)-\min \left\{\left[g_{j}(b)-g_{j}(a)\right], P_{j}\left(g_{j}(a)\right)\right\}}{P_{j}\left(g_{j}(a)\right)-\min \left\{g_{j}\left(g_{j}(a)\right),\left[g_{j}(b)-g_{j}(a)\right]\right\}} & \text { seg } g_{j}(a) \neq 0 \\ 0 & \text { seg } g_{j}(a)=0\end{array}\right\}(16)$

The discordance index is calculated according to Equation 17.

$D_{j}(a, b)=\left\{\begin{array}{lr}\min \left\{1, \max \left\{0, \frac{\left[g_{j}(b)-g_{j}(a)\right]-p_{j}\left(g_{j}(a)\right)}{v_{j}\left(g_{j}(a)\right)-p_{j}\left(g_{j}(a)\right)}\right\}\right\} & \operatorname{seg}_{j}(a) \neq 0 \\ 1 & \operatorname{seg} g_{j}(a)=0\end{array}\right\}$

\section{Global concordance index calculation}

In order to express to what extent the performances of all the criteria are in agreement with the assertion "a is greater than b", the global concordance index $C(a, b)$ (Equation 18) are

Table 3. Weights assigned to the criteria considered in the multiobjective analysis.

\begin{tabular}{lcc}
\hline & \multicolumn{2}{c}{ Weights } \\
\cline { 2 - 3 } Criteria & $\begin{array}{c}\text { Ibatiba, Irupi e } \\
\text { Iúna }\end{array}$ & $\begin{array}{c}\text { S. Trindade e N. S. } \\
\text { das Graças }\end{array}$ \\
\hline Cr 01 & 4.23 & 2.31 \\
Cr02 & 4.42 & 1.73 \\
Cr03 & 8.27 & 5.19 \\
Cr04 & 4.42 & 5.38 \\
Cr05 & 2.50 & 1.92 \\
Cr06 & 4.62 & 6.92 \\
Cr07 & 5.19 & 7.50 \\
Cr08 & 3.27 & 3.27 \\
Cr09 & 4.04 & 3.27 \\
Cr10 & 4.04 & 2.69 \\
Cr11 & 4.04 & 2.69 \\
Cr12 & 4.04 & 2.69 \\
Cr13 & 4.23 & 6.73 \\
Cr14 & 5.00 & 3.65 \\
Cr15 & 5.00 & 3.65 \\
Cr16 & 5.00 & 3.65 \\
Cr17 & 5.00 & 3.65 \\
\hline
\end{tabular}


calculated. The global concordance index consists of the partial concordance indexes $\mathrm{C}_{i}(\mathrm{~b}, \mathrm{a})$ sum in each of the criteria, weighted by each criterion weights, $w_{j}$.

$C(a, b)=\frac{\sum_{j=1}^{n} w_{j} \cdot C_{j}(a, b)}{\sum_{j=1}^{n} w_{j}}$

\section{Credibility index calculation}

Taking into account both the global concordance index and the discordance indices for each criterion, the credibility indexes $\sigma(a, b)$ are established, which comprehensively express to what extent the "a" alternative is considered better than " $\mathrm{b}$ " alternative.

Credibility is merely the global concordance index weakened by the discordance indices. In discordance indices absence, $\sigma(a, b)=C(a, b)$. This credibility value is reduced in one or more discordant criteria presence, when $D_{j}(a, b)>C(a, b)$. In accordance with the veto effect $\sigma(a, b)=0$ if $\exists j \mid D_{j}(a, b)=1$, whatever the importance relative to the criterion, $w_{j}$.

Thus, the credibility index can be defined according to Equation 19.

$\sigma(a, b)=\left\{\begin{array}{lc}C(a, b) & \text { se } \bar{F}(a, b)=\varnothing \\ C(a, b) \times \prod_{j \in \bar{F}(a, b)} \frac{1-D_{j}(a, b)}{1-C(a, b)} & \text { se } \bar{F}(a, b) \neq \varnothing\end{array}\right\}$

\section{Ranking algorithm}

Based on the alternatives credibility indexes, the final ELECTRE III stage consists in the application of a classification algorithm that, through two complete pre-orders results intersection, provides the final sewage treatment systems classification considered in this work.

These two pre-orders are constructed in different ways. The first one is obtained in a decreasing way, starting with the best alternative and ending with the worst attribution - called descending distillation. The second is obtained in ascending order, starting with the worst classified alternative and ending with the assignment of the best - ascending distillation. Dias, Figueira and Roy (2006) present in detail the procedure performed by ELECTRE III-IV software to establish these pre-orders, also presenting a method application example, to facilitate classification algorithm understanding.

\section{RESULTS AND DISCUSSION}

The methodology application results for the Pardo river watershed will be presented in three stages. Firstly, the study area receiving raw sewage releases watercourses assimilation capacities will be discussed. Next, the sewage treatment efficiencies obtained through combined use of the water quality model with the optimization technique estimated for each locality will be presented. Finally, the sewage treatment systems selected for the Pardo river watershed will be presented and discussed, named from this point onwards as WWTP 01 (Ibatiba), WWTP 02 (Irupi), WWTP 03 (Iúna), WWTP 04 (Santíssima Trindade) and WWTP 05 (Nossa Senhora das Graças).

\section{Pardo river watershed water quality modeling considering raw effluents final disposal}

Using the water quality model developed in the MATLAB computational environment, Pardo river watershed three main watercourses DO and BOD concentration profiles were obtained considering final raw sewage disposal (Figures 3, 4 and 5). Table 4 shows, for each locality, the organic load discharged in

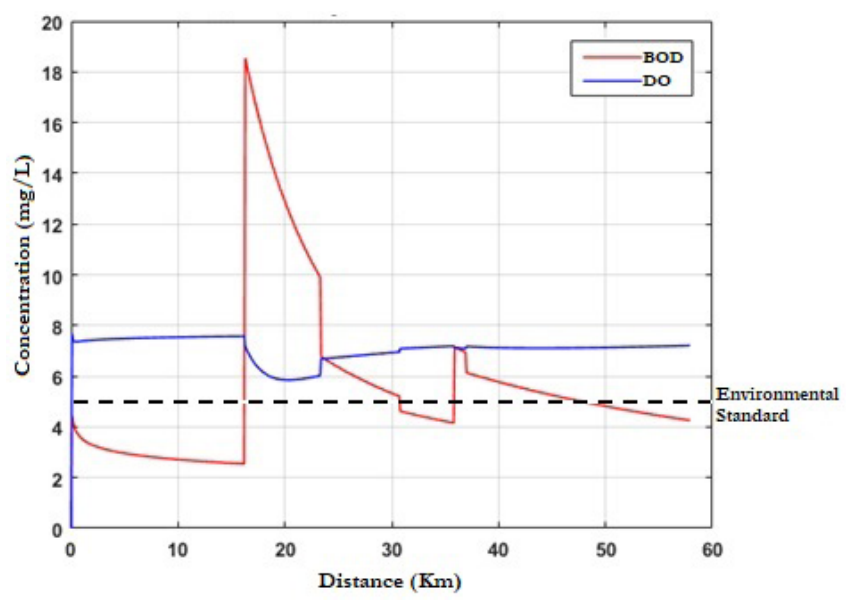

Figure 3. Pardo river DO and BOD concentration profiles.

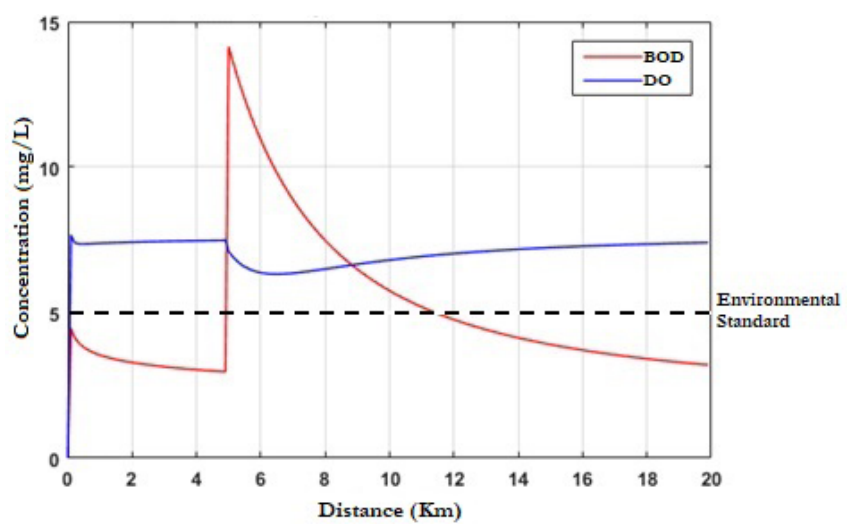

Figure 4. Pardinho river DO and BOD concentration profiles.

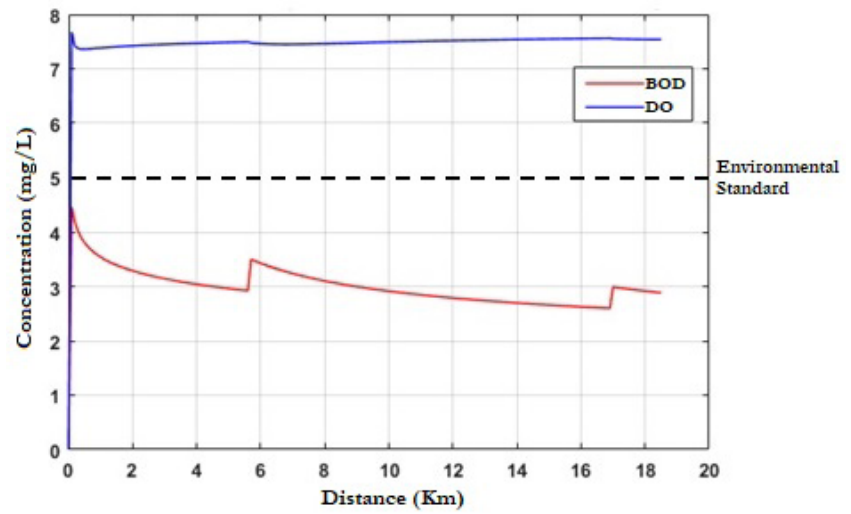

Figure 5. Ribeirão Perdição creek DO and BOD concentration profiles. 
Table 4. Waste load and characteristics of receiving watercourses.

\begin{tabular}{|c|c|c|c|c|}
\hline Pollution Source & $\mathrm{CO}_{\mathrm{e}}(\mathrm{mg} / \mathrm{s})$ & $\mathrm{Q}_{\mathrm{r}}(\mathrm{L} / \mathrm{s})$ & $\mathrm{BOD}_{\mathrm{r}}(\mathrm{mg} / \mathrm{L})$ & $\mathrm{BOD}_{\mathrm{re}}(\mathrm{mg} / \mathrm{L})$ \\
\hline 1 - Ibatiba & 9,720 & 571.6 & 2.55 & 18.54 \\
\hline 2 - Irupi & 2,080 & 172.9 & 2.97 & 14.14 \\
\hline 3 - Iúna & 7,960 & $2,612.2$ & 4.16 & 7.13 \\
\hline 4 - S.Trindade & 120 & 197.6 & 2.92 & 3.50 \\
\hline 5 - $\mathrm{N}^{\mathrm{a}}$ Sra. das Graças & 240 & 596.6 & 2.60 & 2.99 \\
\hline
\end{tabular}

the watercourse $\left(\mathrm{CO}_{\mathrm{e}}\right)$, the water flow immediately upstream the sewage discharge $\left(\mathrm{Q}_{\mathrm{r}}\right)$, and the $\mathrm{BOD}$ concentrations in the water stream immediately upstream the discharge point $\left(\mathrm{BOD}_{\mathrm{r}}\right)$ and at the discharge point $\left(\mathrm{BOD}_{\mathrm{r}_{\mathrm{e}}}\right)$.

From generated concentration profiles analysis and based on CONAMA Resolution 357/2005, even for the estimated Pardo river watershed raw sewage inflow, DO concentrations remained above the $5 \mathrm{mg} / \mathrm{L}$ limit, established for Brazilian Class 2 watercourses. However, with regard to BOD, only Santissima Trindade and Nossa Senhora das Graças communities sewage discharges did confer on the receiving water body (Ribeirão Perdição creek) quality characteristics, DO and BOD, satisfying to Class 2 limit, function of the smaller organic load and the conditions assumed for watercourses sections located upstream the discharge points .

While Irupi wastewater discharges caused a BOD concentration increase slightly higher than $11.0 \mathrm{mg} / \mathrm{L}(11.2 \mathrm{mg} / \mathrm{L})$, at Pardinho River kilometer 5 , the sewage from Ibatiba produced an approximately $16.0 \mathrm{mg} / \mathrm{L}$ increase, at Rio Pardo kilometer 16.3. These localities are the main Pardo river watershed pollution sources.

Due to the lack of domestic sewage inflow, the São José stream affluence, at Rio Pardo Km 23.3, produced considerable dilution effect of the sewage produced by Ibatiba population. Similarly, the Pardinho river affluence, at $\mathrm{Km} 30.8$, and the Ribeirão Perdição creek affluence, at kilometer 37 , caused small BOD concentrations reductions and DO concentrations increases in the Pardo River. The Pardo River BOD peak, located between kilometers 30 and 40 (Figure 3) resulted from Iúna sewage discharge, responsible for an approximately $3.0 \mathrm{mg} / \mathrm{L}$ Biochemical Oxygen Demand increase.

\section{Minimum required BOD removal efficiencies}

Water quality modeling combined with optimization technique provided the necessary treatment efficiencies, for each locality, for the different sewage disposal conditions evaluated (Table 5).

As the main Pardo river watershed pollution source, Ibatiba sewage must be submitted to a treatment process that may guarantee a minimum $90 \%$ BOD removal efficiency, regardless of the final disposal condition evaluated. When considering the BOD discharge restrictions established by CONAMA Resolution 430/2011, Irupi sewage should be submitted to the same treatment level required for Ibatiba. As Irupi discharges the third largest amount of organic load in the watershed in a Pardinho River section that presents a lower dilution capacity, for the third sewage discharge condition (condition that considers the use of self-purification capacity for sewage assimilation) it is necessary an $81.1 \%$ organic matter removal efficiency for the raw sewage generated by its inhabitants.
Table 5. Estimated sewage treatment efficiency.

\begin{tabular}{cccc}
\hline \multirow{2}{*}{ Place } & \multicolumn{3}{c}{ Effluent Discharge Condition } \\
\cline { 2 - 4 } & $\mathbf{1}$ & $\mathbf{2}$ & $\mathbf{3}$ \\
\hline WWTP 01 & $90.0 \%$ & $90.0 \%$ & $90.0 \%$ \\
WWTP 02 & $90.0 \%$ & $90.0 \%$ & $81.1 \%$ \\
WWTP 03 & $90.0 \%$ & $90.0 \%$ & $27.9 \%(<30 \%)$ \\
WWTP 04 & $60.0 \%$ & $70.0 \%$ & $3.9 \%(<30 \%)$ \\
WWTP 05 & $60.0 \%$ & $70.0 \%$ & $2.3 \%(<30 \%)$ \\
\hline
\end{tabular}

As for Irupi, discharge conditions 1 and 2, for Iúna raw sewage there were required the same treatment efficiencies required for Ibatiba's. However, when considering the prospect of Pardo River's self-purification capacity use, the simulations indicated the need to remove only $27.9 \%$ of the organic matter contained in the raw sewage. It is important to note that secondary sewage treatment systems present as minimal BOD removal efficiency approximately $30 \%$, according to treatment systems operating characteristics presented by Von Sperling (2014b).

Considering that Santissima Trindade and Nossa Senhora das Graças communities raw effluents discharges do not result in Ribeirão Perdição creek violation of Class 2 DO and BOD limits, the simulations results always pointed out the smallest possible BOD removal values. When the minimum sewage treatment efficiency was limited to $60 \%$ (discharge condition 1 ), the optimization model indicated the need to install $60 \%$ efficiency sewage treatment plants in both locations. When assumed $120 \mathrm{mg} / \mathrm{L}$ maximum BOD (discharge condition 2), 70\% treatment efficiencies were required (minimum efficiency required for $120 \mathrm{mg} / \mathrm{L}$ BOD, considering the adopted raw sewage characteristics). For the third discharge condition, for which the minimum sewage treatment efficiency could be $1 \%$, the model indicated the need to remove only $3.9 \%$ and $2.3 \%$ of the BOD from the sewage generated by Santíssima Trindade and Nossa Senhora das Graças inhabitants. Thus, the results associated with discharge conditions 1 and 2 demonstrate that the restrictions imposed by CONAMA Resolution 430/2011, which ignore water bodies self-purification capacities use possibility ( $60 \%$ minimum BOD removal efficiencies or maximum $120 \mathrm{mg}$ / L BOD), would lead to a significant increase in effluent treatment efficiencies, leading to the selection of more robust sewage treatment systems and, possibly, inadequate distribution of the generally limited financial resources allocated to wastewater treatment plants implementation and operation.

It can be stated that, in general, the water bodies effluents assimilation capacities were adequately distributed among the polluters. The water flow and quality conditions immediately prior to receiving sewage had a direct influence on the estimated treatment efficiencies, as sought by the objective function established 
in Equation 1. This perspective can be observed from the analysis of the results presented for Ibatiba and Iuna, when considered the sewage discharge third condition. These locations, although presenting very close organic loads (Table 4), required very distinct treatment efficiencies (90.0 and $27.9 \%$, respectively), since Pardo river assimilation capacity at the Iuna sewage discharge point was considerably higher than that of the same watercourse when receiving Ibatiba discharge. It should be noted that in Santoro, Reis and Mendonça (2016) work - whose optimization models did not consider the condition of the recipient bodies immediately upstream raw domestic sewage inputs - the estimated treatment efficiency for Iúna reached $94 \%$.

Although the results obtained for discharge condition 3 indicate the need of less than 30\% BOD removal efficiencies for Iuna, Santíssima Trindade and Nossa Senhora das Graças sewage, sewage treatment systems were also proposed for these locations, as presented in the subsequent topic.

\section{Pardo river watershed sewage treatment systems selection}

After obtaining the minimum BOD removal efficiencies required for each locality, those treatment alternatives presenting lower efficiencies as well as those alternatives that involved soil effluent disposal were excluded from the initial set of 30 (thirty). Thus, Table 6 presents the alternatives that have passed to the multiobjective analysis process.

It is important to note that, although the alternatives listed in Table 6 were considered, possible local technical conditions (such as terrain slope, hydrogeological characteristics and available area) could have restricted the consideration of some alternatives analyzed in this study. Nevertheless, Table 7 presents the synthesis of the sewage treatment systems selected for the five Pardo river watershed effluent disposal points, after ELECTRE III application.

From Table 7 analysis, the treatment systems selected for Ibatiba (WWTP 01) were identical (A29 - Submersed Aerated Biofilter with Nitrification) for the three final effluents disposal conditions evaluated, since the efficiency removal required for the Ibatiba remained constant $(\mathrm{E} 1=90 \%)$. The results provided by ELECTRE III, for Ibatiba, are available in Table 8 and Figures 6 and 7.

The final sewage treatment systems ordering (Figure 7) was made by the ELECTRE III software from the results of the up and down distillations (Figure 6), calculated on the basis of credibility indices values (Table 8). As alternative A29 was ranked better than alternative $\mathrm{A} 30$ in the descending distillation and since both treatment systems were also classified in the ascending distillation, A29 took the first place in the ordering made by ELECTRE III, while A30 took the second place. Similarly, as in one of the distillations the alternative A30 assumed better classification than the alternatives A25 and A26, and the same classification in the other pre-order, the sewage treatment system A30 was considered superior to the treatment systems A25 and A26. On the other hand, treatment systems A25 and A26 were considered indifferent because they belonged to the same equivalence class in the two pre-orders and, therefore, assumed the third place in the final ordering. It is important to highlight that among the four alternatives evaluated for Ibatiba, the Submerged Aerated Biofilter with Nitrification resulted as the most advantageous treatment system from the economic point of view. Thus, the veto threshold incorporation (in this work considered only in the criteria related to costs) had a considerable influence on the results obtained, since it made

Table 6. Sewage treatment alternatives considered in the multiobjective analysis.

\begin{tabular}{|c|c|c|c|}
\hline \multirow{2}{*}{ WWTP } & \multicolumn{3}{|c|}{ Effluent Discharge Condition } \\
\hline & 1 & 2 & 3 \\
\hline WWTP 01 & A25, A26, A29 e A30 & A25, A26, A29 e A30 & A25, A26, A29 e A30 \\
\hline WWTP 02 & Idem WWTP 01 & Idem WTTP 01 & $\begin{array}{c}\text { A07, A08, A09, A13, A14, A16, A17, } \\
\text { A19, A20, A24, A25, A26, A27, A28, } \\
\text { A29 e A30 }\end{array}$ \\
\hline WWTP 03 & Idem WWTP 01 & Idem WWTP 01 & $\begin{array}{c}\text { A01, A02, A03, A04, A05, A06, A07, } \\
\text { A08, A09, A13, A14, A15, A16, A17, } \\
\text { A18, A19, A20, A21, A22, A24, A25, } \\
\text { A26, A27, A28, A29 e A30 }\end{array}$ \\
\hline WWTP 04 e WWTP 05 & $\begin{array}{c}\text { A02, A03, A04, A05, A06, A07, A08, } \\
\text { A09, A13, A14, A15, A16, A17, A18, } \\
\text { A19, A20, A21, A22, A24, A25, A26, } \\
\text { A27, A28, A29 e A30 }\end{array}$ & $\begin{array}{c}\text { A03, A04, A05, A06, A07, A08, A09, } \\
\text { A13, A14, A15, A16, A17, A18, A19, } \\
\text { A20, A21, A22, A24, A25, A26, A27, } \\
\text { A28, A29 e A30 }\end{array}$ & Idem WWTP 03 \\
\hline
\end{tabular}

Table 7. Sewage treatment alternatives selected by ELECTRE III.

\begin{tabular}{cccc}
\hline WWTP & \multicolumn{3}{c}{ Effluent Discharge Condition } \\
\cline { 2 - 4 } & $\mathbf{1}$ & $\mathbf{2}$ & $\mathbf{3}$ \\
WWTP 01 & A29 & A29 & A29 \\
WWTP 02 & A29 & A29 & A13 \\
WWTP 03 & A29 & A29 & A13 \\
WWTP 04 & A03 ou A13 & A03 ou A13 & A03 ou A13 \\
WWTP 05 & A03 ou A13 & A03 ou A13 & A03 ou A13 \\
\hline
\end{tabular}


Table 8. Credibility matrix for treatment alternatives considered in the multiobjective analysis for WWTP 01 (Ibatiba) choice.

\begin{tabular}{ccccc}
\hline Alternative & A25 & A26 & A29 & A30 \\
\hline A25 & 1 & 1 & 0 & 0 \\
A26 & 0.97 & 1 & 0 & 0 \\
A29 & 0.96 & 0.96 & 1 & 0 \\
A30 & 0 & 0 & 0 & 1 \\
\hline
\end{tabular}

Alternative $\mathrm{A}$ to alternative $\mathrm{B}$ credibility index lies in the line $\mathrm{A}$ with column $\mathrm{B}$ intersection cell.

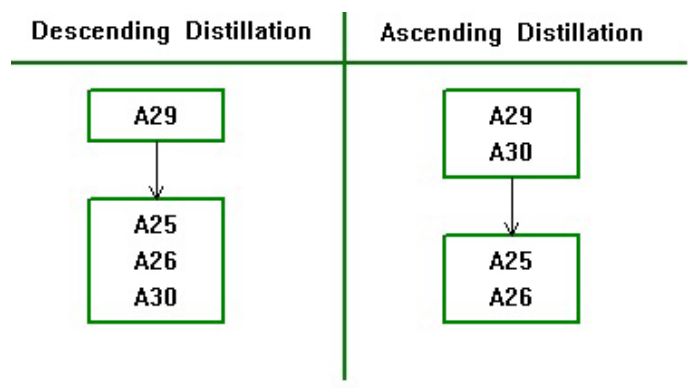

Figure 6. Result of distillations carried out by ELECTRE III.

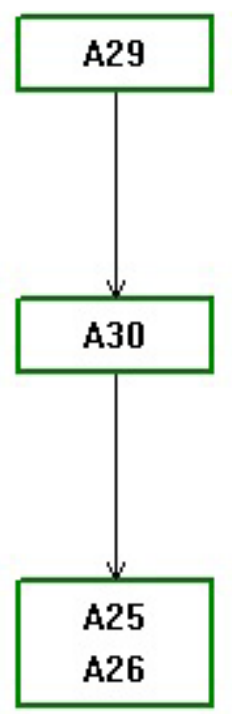

Figure 7. Final order carried out by ELECTRE III.

that the alternatives most benefited by its effect assumed at least good placement in the final ordering.

When required 90\% minimum efficiencies, the sewage treatment systems selected for Irupi (WWTP 02) and Iuna (WWTP 03) were the same ones selected for Ibatiba, since the same weights and criteria were considered in the multiobjective analysis.

When required treatment efficiencies for Irupi and Iuna, $81.1 \%$ and $27.9 \%$ (WW'TP's 02 and 03 , respectively), the Wetland type system was recommended for both locations, presenting as advantages practically zero energy requirements, high BOD removal efficiency, simple construction, operation and maintenance, reduced implantation and operation costs, good resistance to load variations and no sludge generation. It is important to highlight that the selected alternative presented one of the lowest implantation and operation costs (criteria influenced by the veto effect) when compared to the other treatment systems that entered the multiobjective analysis, besides presenting one of the best coliforms removal performances (criterion presenting greater weight in the selection process). Nevertheless, in general, the aforementioned treatment system has good performance in most of the analysis criteria considered in the selection process, which favors its good placement in the ELECTRE III hierarchy. It is important to note that the choice of the same system (Wetland type) for Irupi and Iuna, with considerably different treatment efficiencies (27.9 and $81.1 \%$ ), indicates the need to incorporate, in the multiobjective analysis, a criterion regarding the BOD removal efficiency. Such incorporation would probably make it possible for the multiobjective analysis results to be closer to those provided by water quality simulation model and optimization technique application.

Regardless of the required BOD removal efficiencies, two treatment systems took the first place in the final order indicated by ELECTRE III for Santíssima Trindade (WWTP 04) and Nossa Senhora das Graças (WWTP 05) communities: Facultative Pond (A03) and Wetland (A13). As Facultative Ponds advantages, it is worth noting the satisfactory BOD removal efficiency, simple construction, operation and maintenance, practically zero energy requirements, sludge removal required only after periods of more than 20 years and reduced implementation and operating costs. It is important to note that for the WWTP 03 (Iuna) choice the greatest relevance multiobjective analysis criterion consisted of the coliform removal efficiency, for Trindade (WWTP 04) and Nossa Senhora das Gracas (WWTP 05) the greater criteria weight in the multiobjective analysis were related with implementation and operation costs, as well as operational simplicity. Thus, even starting from the same treatment alternatives set (for WWTP 03, WWTP 04 and WWTP 05, treatment efficiencies lower than $30 \%$ were required), the results for the third sewage discharge condition were influenced by differences in the criteria weights.

\section{CONCLUSIONS}

From water quality model combined with an optimization technique and multiobjective analysis application results, the main conclusions of this work can be summarized, as follows:

- Final disposal of raw sewage, regardless of the scenario considered, would not allow compliance with the water quality standards associated with BOD established for Brazilian CONAMA class 2 watercourses in long Pardo and Pardinho rivers stretches;

- The use of the water quality model combined with the optimization technique allowed the appropriation of minimum BOD removal efficiencies for the different Pardo river watershed effluent disposal points, seeking the most equitable distribution of watercourses assimilation capacities among polluters. In simulations where the minimum BOD removal levels or maximum BOD concentrations indicated by Brazilian environmental legislation were 
considered as constraints on the optimization problem (discharge conditions 1 and 2), efficiencies ranged from 60 to $90 \%$. In scenarios where these restrictions were not incorporated into the optimization model efficiencies ranged from approximately $3 \%$ to $90 \%$. Thus, ignoring water bodies self-purification capacities may can lead to significant increase in required effluent treatment efficiencies, overestimation of treatment plants and, possibly, inadequate distribution of financial resources, usually limited, for WWTP's implementation and operation;

The application of ELECTRE III allowed to indicate the treatment systems considered most appropriate, within the analysis context, for each Pardo River watershed raw sewage discharge point. Multiobjective analysis results demonstrated that the method is sensitive to each criterion weights variations and to the adoption of veto thresholds. Whenever required removal efficiencies above 90\%, ELECTRE III indicated the Submerged Aerated Biofilter system (with Nitrification) as an alternative treatment. The Wetland type treatment system was indicated for different locations and different discharge conditions. In some cases, both the Facultative Ponds and the Wetlands were selected as the first treatment option;

The sewage treatment systems indicated for the Pardo river watershed five localities are associated with the analysis context considered, resulting from the preference structure adopted. In this way, the establishment of a diverse preference structure or the incorporation of local technical restrictions, fundamental to the decision-making processes, could restrict some treatment technologies implementation.

The use of water quality simulation model and optimization technique, prior to the application of multiobjective analysis, has proved to be relevant in the sewage treatment systems selection context, since it includes, in the appropriate technology search, watercourses self-purification capacity analysis. This approach allowed to indicate sewage treatment systems, at the river watershed level, considering the "Polluter Pays Principle" and aiming at minimizing required treatment efficiencies (by taking advantage of watercourses self-purification capacities). However, the results indicated the need to adopt, in the multiobjective analysis, the criterion associated to BOD removal efficiency (in this work, the BOD removal efficiency constituted a criterion applied to the sewage treatment systems pre-selection), to avoid selecting the same types of sewage treatment systems for locations where the required minimum efficiencies are much different.

\section{REFERENCES}

ACHILLAS, C.; MOUSSIOPOULOS, N.; KARAGIANNIDIS, A.; BANIAS, G.; PERKOULIDIS, G. The use of multi-criteria decision analysis to tackle waste management problems: a literature review. Waste Management \& Research, v. 31, n. 2, p. 115-129, 2013. http://dx.doi.org/10.1177/0734242X12470203. PMid:23315368.

ANA - AGÊNCIA NACIONAL DE ÁGUAS. Atlas esgotos: despoluição de bacias hidrográficas. Brasília, 2017.

ARAS, E.; TOGAN, V.; BERKUN, M. River water quality management model using genetic algorithm. Enviromental Fluidic Mechanical, v. 7, n. 5, p. 439-450, 2007. http://dx.doi.org/10.1007/ s10652-007-9037-4.

ASHTIANI, E. F.; NIKSOKHAN, M. H.; JAMSHIDI, S. Equitable fund allocation, an economical approach for sustainable waste load allocation. Environmental Monitoring and Assessment, v. 187, n. 8, p. 522, 2015. http://dx.doi.org/10.1007/s10661-015-4739-4. PMid:26205280.

BOTTERO, M.; COMINO, E.; RIGGIO, V. Application of the Analytic Hierarchy Process and the Analytic Network Process for the assessment of different wastewater treatment systems. Environmental Modelling \& Software, v. 26, n. 10, p. 1211-1224, 2011. http://dx.doi.org/10.1016/j.envsoft.2011.04.002.

BRASIL. Lei no 9.433, de 8 de janeiro de 1997. Institui a Política Nacional de Recursos Hídricos, cria o Sistema Nacional de Gerenciamento de Recursos Hídricos, regulamenta o inciso XIX do art. 21 da Constituição Federal, e altera o art. $1^{\circ}$ da Lei no 8.001 , de 13 de março de 1990, que modificou a Lei no 7.990, de 28 de dezembro de 1989. Diário Oficial [da] República Federativa do Brasil, Brasília, DF, 9 jan. 1997.

BRASIL. Ministério do Meio Ambiente. Conselho Nacional do Meio Ambiente. Resolução CONAMA no 357, de 17 de março de 2005. Dispõe sobre a classificação dos corpos de água e diretrizes ambientais para o seu enquadramento, bem como estabelece as condições e padrões de lançamento de efluentes, e dá outras providências. Diário Oficial [da] República Federativa do Brasil, Brasília, DF, 18 mar. 2005.

BRASIL. Lei n ${ }^{\circ} 11.445$, de 5 de janeiro de 2007. Estabelece diretrizes nacionais para o saneamento básico; altera as Leis nos 6.766, de 19 de dezembro de 1979, 8.036, de 11 de maio de 1990, 8.666, de 21 de junho de 1993, 8.987, de 13 de fevereiro de 1995; revoga a Lei no 6.528, de 11 de maio de 1978; e dá outras providências. Diário Oficial [da] República Federativa do Brasil, Brasília, DF, 8 jan. 2007.

BRASIL. Ministério do Meio Ambiente. Conselho Nacional do Meio Ambiente. Resolução CONAMA nº 430, de 13 de maio de 2011. Dispõe sobre as condições e padrões de lançamento de efluentes, complementa e altera a Resolução no 357, de 17 de março de 2005, do Conselho Nacional do Meio Ambiente CONAMA. Diário Oficial [da] República Federativa do Brasil, Brasília, DF, 16 maio 2011.

BURN, D. H.; YULIANTI, J. S. Waste-load allocation using genetic algorithms. Journal of Water Resources Planning and Management, v. 127, n. 2, p. 121-129, 2001. http://dx.doi.org/10.1061/(ASCE)07339496(2001)127:2(121). 
CALMON, A. P. S.; SOUZA, J. C.; REIS, J. A. T.; MENDONÇA, A. S. F. Uso combinado de curvas de permanência de qualidade e modelagem da autodepuração como ferramenta para suporte ao processo de enquadramento de cursos d'água superficiais. Revista Brasileira de Recursos Hídricos, v. 21, n. 1, p. 118-133, 2016. http:/ / dx.doi.org/10.21168/rbrh.v21n1.p118-133.

CASTILLO, A.; VALL, P.; GARRIDO-BASERBA, M.; COMAS, J.; POCH, M. Selection of industrial (food, drink and milk sector) wastewater treatment technologies: a multi-criteria assessment. Journal of Cleaner Production, v. 143, p. 180-190, 2017. http://dx.doi. org/10.1016/j.jclepro.2016.12.132.

CHO, J. H.; LEE, J. H. Multi-objective waste load allocation model for optimizing waste load abatement and inequality among waste dischargers. Water, Air, and Soil Pollution, v. 225, n. 3, p. 1892, 2014. http:/ /dx.doi.org/10.1007/s11270-014-1892-2.

CHO, J. H.; SEOK SUNG, K.; RYONG HA, S. A river water quality management model for optimizing regional wastewater treatment using a genetic algorithm. Journal of Environmental Management, v. 73, n. 3, p. 229-242, 2004. http://dx.doi.org/10.1016/j. jenvman.2004.07.004. PMid:15474740.

CORDEIRO NETTO, O. M.; SOUZA, M. A. A.; LOPES JÚNIOR, R. P. Retrospectiva e prospectiva da análise tecnológica das alternativas para pós-tratamento de efluentes de reatores anaeróbios. In: CHERNICHARO, C. A. L. (Ed.). Pós-tratamento de efluentes de reatores anaeróbios: coletânea de trabalhos técnicos. 1. ed. Belo Horizonte: Programa de Pesquisa em Saneamento Básico, Financiadora de Estudos e Projetos, 2001. v. 2, p. 253-272.

CORNELLI, R. Análise e seleção de alternativas sustentáveis de esgotamento sanitário. 2014. 136 f. Tese (Doutorado em Engenharia) - Escola de Engenharia, Universidade Federal do Rio Grande do Sul, Porto Alegre, 2014.

DIAS, J. A.; FIGUEIRA, J. R.; ROY, B. The software Electre III-IV: methodology and user manual. Paris: Laboratory for Analysis and Modelling of Decision Support Systems, 2006.

EPA - UNITED STATES ENVIRONMENTAL PROTECTION AGENCY. Rates, constants, and kinetics formulations in surface water quality modeling. 2nd ed. Athens, 1985. 445 p.

FANTIN, L. L. D.; REIS, J. A. T.; MENDONÇA, A. S. F. Proposal of a methodology for pre-selection of sewage treatment systems within watersheds. Revista Brasileira de Recursos Hidricos, v. 22, n. 0 , p. e-12, 2017. http://dx.doi.org/10.1590/2318-0331.011716079.

GARCIA, J. I. B. Sistema de suporte a decisão para o lançamento de efluentes. 2011. 182 f. Tese (Doutorado em Engenharia Hidráulica) - Escola Politécnica, Universidade de São Paulo, São Paulo, 2011.

GEN, M.; CHENG, R. Genetic algorithms \& engineering design. New York: John Wiley \& Sons, 1996. http://dx.doi.org/10.1002/9780470172254.

GOLFI, A. S. Uso da análise multicritério para a seleção de tecnologias de tratamento de efluentes. 2017. 113 f. Dissertação (Mestrado) -
Programa de Pós-graduação em Engenharia de Produção e Sistemas, Universidade Tecnológica do Paraná, Pato Branco, 2017.

GREFENSTETTE, J. J. Optimization of control parameters for genetic algorithms. IEEE Transactions on Systems, Man, and Cybernetics, v. 16, n. 1, p. 122-128, 1986. http://dx.doi.org/10.1109/ TSMC.1986.289288.

HAMOUDA, M. A.; ANDERSON, W. B.; HUCK, P. M. Decision support systems in water and wastewater treatment process selection and design: a review. Water Science and Technology, v. 60, n. 7, p. 1757-1770, 2009. http://dx.doi.org/10.2166/wst.2009.538. PMid:19809138.

HAN, K.; NOH, J.; KIM, J.; LEE, C. Application of stochastic optimization algorithm for waste load allocation in the Nakdong River Basin, Korea. KSCE Journal of Civil Engineering, v. 16, n. 4, p. 650-659, 2012. http://dx.doi.org/10.1007/s12205-012-0919-8.

HUANG, I. B.; KEISLER, J.; LINKOV, I. Multi-criteria decision analysis in environmental sciences: ten years of applications and trends. The Science of the Total Environment, v. 409, n. 19, p. 3578 3594, 2011. http://dx.doi.org/10.1016/j.scitotenv.2011.06.022. PMid:21764422.

HUNT, C. C. Modelo multicritério de apoio à decisão aplicado à seleção de sistema de tratamento de esgoto para pequenos municípios. 2013. 118 f. Dissertação (Mestrado em Engenharia Ambiental) - Programa de Engenharia Ambiental, Escola Politécnica e Escola de Química, Universidade Federal do Rio de Janeiro, Rio de Janeiro, 2013.

JORDÃO, E. P.; PESSOA, C. A. Tratamento de esgotos domésticos. 7. ed. Rio de Janeiro: ABES, 2014. 1050 p.

KALBAR, P. P.; KARMAKAR, S.; ASOLEKAR, S. R. Selection of an appropriate wastewater treatment technology: a scenariobased multiple-attribute decision-making approach. Journal of Environmental Management, v. 113, p. 158-169, 2012. http://dx.doi. org/10.1016/j.jenvman.2012.08.025. PMid:23023038.

KARIMI, A. R.; MEHRDADI, N.; HASHEMIAN, S. J.; BIDHENDI, G. R. N.; MOGHADDAM, R. T. Selection of wastewater treatment process based on the analytical hierarchy process and fuzzy analytical hierarchy process methods. International Journal of Environmental Science and Technology, v. 8, n. 2, p. 267-280, 2011. http://dx.doi.org/10.1007/BF03326215.

LACERDA, E. G. M.; CARVALHO, A. C. P. L. F. Introdução aos algoritmos genéticos. In: GALVÃO, C. O.; VALENÇA, M. J. S. (Ed.). Sistemas inteligentes: 121 aplicações a recursos hídricos e ciências ambientais. Porto Alegre: Editora UFRGS, 1999. p. 99-150.

LEI, K.; ZHOU, G.; GUO, F.; KHU, S.; MAO, G.; PENG, J.; LIU, Q. Simulation-optimization method based on rationality evaluation for waste load allocation in Daliao river. Environmental Earth Sciences, v. 73, n. 9, p. 5193-5209, 2015. http://dx.doi. org/10.1007/s12665-015-4334-6.

LEIRAS, A. Otimização de parâmetros de um algoritmo genético. Revista de Inteligência Computacional Aplicada, n. 6, p. 1-8, 2010. 
MAHJOURI, N.; BIZHANI-MANZAR, M. Waste load allocation in rivers using Fallback Bargaining. Water Resources Management, v. 27, n. 7, p. 2125-2136, 2013. http://dx.doi.org/10.1007/s11269013-0279-2.

MARTTUNEN, M.; LIENERT, J.; BELTON, V. Structuring problems for multi-criteria decision analysis in practice: a literature review of method combinations. European Journal of Operational Research, v. 263, n. 1, p. 1-17, 2017. http://dx.doi.org/10.1016/j. ejor.2017.04.041.

MOLINOS-SENANTE, M.; GÓMEZ, T.; CABALLERO, R.; HERNÁNDEZ-SANCHO, F; SALA-GARRIDO, R. Assessment of wastewater treatment alternatives for small communities: An analytic network process approach. The Science of the Total Environment, v. 532, p. 676-687, 2015. http://dx.doi.org/10.1016/j. scitotenv.2015.06.059. PMid:26119382.

NICKLOW, J.; REED, P.; SAVIC, D.; DESSALEGNE, T.; HARRELL, L.; CHAN-HILTON, A.; KARAMOUZ, M.; MINSKER, B.; OSTFELD, A.; SINGH, A.; ZECHMAN, E. State of the art for genetic algorithms and beyond in water resources planning and management. Journal of Water Resources Planning and Management, v. 136, n. 4, p. 412-432, 2010. http://dx.doi.org/10.1061/(ASCE) WR.1943-5452.0000053.

NIKOO, M. R.; BEIGLOU, P. H. B.; MAHJOURI, N. Optimizing Multiple-Pollutant waste load allocation in rivers: an interval parameter Game Theoretic Model. Water Resources Management, v. 30, n. 12, p. 4201-4220, 2016. http://dx.doi.org/10.1007/ s11269-016-1415-6.

NIKOO, M. R.; KERACHIAN, R.; NIKSOKHAN, M. H. Equitable waste load allocation in rivers using Fuzzy Bi-matrix Games. Water Resources Management, v. 26, n. 15, p. 4539-4552, 2012. http://dx.doi.org/10.1007/s11269-012-0165-3.

OUYANG, X.; GUO, F.; SHAN, D.; YU, H.; WANG, J. Development of the integrated fuzzy analytical hierarchy process with multidimensional scaling in selection of natural wastewater treatment alternatives. Ecological Engineering, v. 74, p. 438-447, 2015. http:/ /dx.doi.org/10.1016/j.ecoleng.2014.11.006.

POZO, A. Computação evolutiva. Curitiba: Grupo de Pesquisas em Computação Evolutiva, Departamento de Informática, Universidade Federal do Paraná, 2005. Disponível em: <http://www.inf.ufpr. br/aurora/tutoriais/Ceapostila.pdf>. Acesso em: 8 maio 2017.

RAHM, B. G.; VEDACHALAM, S.; SHEN, J.; WOODBURY, P. B.; RIHA, S. J. A watershed-scale goals approach to assessing and funding wastewater infrastructure. Journal of Environmental Management, v. 129, p. 124-133, 2013. http://dx.doi.org/10.1016/j. jenvman.2013.06.053. PMid:23911765.

SANTORO, M. C.; REIS, J. A. T.; MENDONÇA, A. S. F. Performance evaluation of optimization models in the determination of wastewater treatment efficiencies inside watersheds. Revista
Brasileira de Recursos Hídricos, v. 21, n. 4, p. 694-706, 2016. http:/ / dx.doi.org/10.1590/2318-0331.011616031.

SOUZA, A. A. M.; FORSTER, L. C. Metodologias para a seleção de processos de tratamento de águas residuárias. Revista Engenharia Sanitária e Ambiental, v. 2, n. 1, p. 19-31, 1996.

SOUZA, M. A. A.; CORDEIRO, B. S.; SILVA, C. L. Avaliação multiobjetivo e multicritério de alternativas de gestão de lodo de fossa / tanque séptico. In: ANDREOLI, C. V. (Ed.). Lodo de fossa e tanque séptico: caracterização, tecnologias de tratamento, gerenciamento e destino final. 1. ed. Curtiba: ABES, PROSAB, FINEP, 2009. v. 1, p. 327-374.

TANOMARU, J. Motivação, fundamentos e aplicações de algoritmos genéticos. In: CONGRESSO BRASILEIRO DE REDES NEURAIS, 2., 1995, Curitiba, PR. Anais... Curitiba: ABRICOM, 1995. p. 373-403, .

THOMANN, R. V.; MUELLER, J. A. Principles of surface water quality modeling and control. New York: Harper \& Row, 1987.

VALORY, J. P. L.; REIS, J. A. T.; MENDONÇA, A. S. F. Combining Genetic Algorithms with a water quality model to determine efficiencies of sewage treatment systems in watersheds. Journal of Environmental Engineering, v. 142, p. 04015080-04015080-9, 2016.

VON SPERLING, M. Estudos e modelagem da qualidade da água de rios. Belo Horizonte: Departamento de Engenharia Sanitária e Ambiental, UFMG. 2007.

VON SPERLING, M. Estudos e modelagem da qualidade da água de rios. 2. ed. Belo Horizonte: Editora UFMG, 2014a. 592 p.

VON SPERLING, M. Introdução à qualidade das águas e ao tratamento de esgotos. 4. ed. Belo Horizonte: Editora UFMG, 2014b. 472 p.

ZENG, G.; JIANG, R.; HUANG, G.; XU, M.; LI, J. Optimization of wastewater treatment alternative selection by hierarchy grey relational analysis. Journal of Environmental Management, v. 82, n. 2, p. 250-259, 2007. http://dx.doi.org/10.1016/j.jenvman.2005.12.024. PMid:16635543.

\section{Authors contributions}

Luiza Mayer Bringer: Acquisition of data, selection and application of optimization technique and multiobjective analysis, analysis and interpretation of results, drafting of manuscript and critical revision.

José Antonio Tosta dos Reis: Analysis and interpretation of results, drafting of manuscript and critical revision.

Antonio Sérgio Ferreira Mendonça: Analysis and interpretation of results, drafting of manuscript and critical revision. 